\title{
MISRECOGNITION UNMASKED? 'POLYNOMIC' LANGUAGE, EXPERT STATUSES AND ORTHOGRAPHIC PRACTICES IN CORSICAN SCHOOLS
}

\author{
Alexandra Jaffe
}

\begin{abstract}
Over the last twenty years, "expert" discourses about the sociolinguistic character of Corsica have shifted from a focus on "diglossia" to an assertion that Corsican is a "polynomic" language. In the context of language shift and efforts at minority language revitalization, these two discourses make different claims about the relationship of language and identity, posit different kinds of power relationships between Corsicans and their two languages, and have different implications for Corsican language policy and advocacy. One of the unintended consequences of a revitalization program built on the idea of "diglossia" was the internal reproduction of dominant language hierarchies that divided rather than unified Corsicans around language. As an antidote, Corsican academics in the late eighties, introduced the notion of Corsican as a "polynomic" language defined both by its internal variation (multiple centers of "authenticity" and "authority") and by speakers' recognition of linguistic unity in diversity - a collective stance vis-à-vis linguistic variation that challenges the very principles of dominant (French) language ideologies in its inclusive, non-hierarchical nature. Through analysis of ethnographic data from a month-long bilingual teacher training course and from the way that Corsican orthography is taught in a bilingual school, I explore the ideology of polynomic unity in diversity and how it misrecognizes 1) contemporary speakers' relationship with regional variation and 2) the new forms of linguistic diversity caused by language shift among both students and teachers in Corsican bilingual classrooms.
\end{abstract}

Keywords: Corsica, Polynomy, Orthography, Ideology.

\section{Introduction}

Over the last twenty years, "expert" discourses about the sociolinguistic character of Corsica have shifted from a focus on "diglossia" to an assertion that Corsican is a "polynomic" language: A language, in the words of Jean-Baptiste Marcellesi "with an abstract unity, recognized by its users in several modalities of existence; all of them are equally tolerated and they are not ranked or functionally specialized. It is accompanied by phonological and morphological intertolerance between users of different varieties; moreover, lexical multiplicity is seen as a source of richness (1989: 170; my translation). Both the discourse on diglossia and the discourse on polynomy seek to demystify the "misrecognition" of structures and processes of domination built into dominant language ideologies and practices. Both discourses are founded on the conviction that misrecognition has made Corsicans complicit in social processes that have led to language shift towards French, and that the revitalization of Corsican depends on exposing and shifting the bases of social and linguistic power. However, these discourses differ critically in how they frame 
Corsican linguistic variation in relation to cultural identity and have different implications for Corsican language policy and advocacy. The shift in expert discourse towards "polynomy" can be viewed as a expansion and refinement of Corsican language planners' and academics' thinking about misrecognition; whereas talking about "diglossia" focused attention on the imbalance of power between Corsican and French, and how stigma was reproduced institutionally and internalized at a personal level, "polynomy" drew attention to the underlying ideas about linguistic unity and identity that fueled processes of linguistic stratification. Alerted to the fact that a revitalization program built on the idea of "diglossia" had inadvertently produced Corsican language hierarchies that divided rather than unified Corsicans around language, Corsican academics promoted the idea of Corsican as a "polynomic" language defined both by its internal variation (multiple centers of "authenticity" and "authority") and by speakers' recognition of linguistic unity in diversity a collective stance vis- à-vis linguistic variation that challenges the very principles of dominant (French) language ideologies in its inclusive, non-hierarchical nature.

My interest here is to look at how polynomy as an expert discourse gets translated into evaluative practice in a key socializing institution: The schools. For, as Bourdieu pointed out long ago, misrecognition lives through embedded criteria of evaluation that structure the educational habitus (1988). Below, I assess the extent to which polynomic ideologies of language and identity are reflected in linguistic and metalinguistic practice in Corsican bilingual education, looking at both teachers' and students' representations of linguistic authority across a variety of classroom events and with detailed reference to orthographic evaluations on an experimental task. My analysis focuses on two sources of tension in the application of the notion of polynomy to school settings. First, there are institutional habits and constraints which tend to impose the notion of a single authoritative standard. Secondly, there is gap between the imagined speech community embedded in the polynomic model (a speech community made up of competent speakers of diverse regional dialects of Corsican) and the reality of speakers with partial competencies - that is, speakers whose linguistic diversity is not just regional, but a function of language shift and contact. This analysis is used to reflect on two issues: First on the potential for dominant ideologies of language and identity to be challenged by pluralistic models in educational context and second, on the extent to which misrecognition is built in to all political discourses about language.

\section{Brief history of the development of "polynomy"}

In the first phase of Corsican language planning, Corsican academics introduced the concept of diglossia into public discourse. Talking about diglossia was a way of understanding the process of language domination and shift from both a societal and a personal, psychological perspective. On the macro-level, diglossia described the functional, social outcomes of French language dominance, in particular, the stigmatization and exclusion of Corsican as a dialect or patois in high-status domains of social life, notably in powerful institutions like the school. On the personal level, diglossia was represented almost as a disease of misrecognition, and was likened to the internalization of race stigma in the colonial context; in fact, on my first visit to Corsica, I was told by several people that I needed to read Franz Fanon's book Black Skin, White Masks and Albert Memmi's The 
Colonizer and the Colonized if I wanted to understand the Corsican cultural and linguistic experience. Overall, then, diglossia was a way of exposing the processes of linguistic domination and understanding the collective sociolinguistic psyche that it created. In a way, it was an effort to lift a psychological burden from individual Corsicans: They could not be responsible for having a disease whose vector was a powerful State. ${ }^{1}$

Diglossia was also a framework for action by language planners. First, as I have suggested, it focused their energies on keeping the issue of power at the forefront of public discourse, showing that Corsican's low prestige and declining use was a function of historical processes of domination and not an index of any inherent deficit of the language itself. Secondly, it acted as a blueprint for status and corpus planning. If diglossia was an outcome and a cause of language shift, then reversing language shift had to be about upending the language hierarchies of a diglossic system. This tactic was not so concerned with treating the disease of misrecognition as it was with improving the material conditions of Corsican in Corsican society with the expectation that doing so would diminish the negative linguistic self-image that went along with diglossia.

One of the unintended consequences of Corsican status and corpus planning was the creation of new rifts in Corsican society created around the presence of (or the threat of) new forms of Corsican-internal linguistic hierarchy. In public discourse about language planning, the regional dialectal diversity of Corsican was often presented as an obstacle to the normalization and standardization that were seen as prerequisites for Corsican to take its place in formal, official institutions and domains. "How can we teach Corsican in school," some people asked, "if we can't agree on what Corsican to teach?"

In the early 1990s, sociolinguists at the University of Corsica organized a conference around the theme of polynomy and Marcellesi and a number of other Corsican scholars asserted that Corsican was a polynomic language: That its speakers recognized unity in diversity. While responding to diglossia pushed Corsican language planners to prove Corsican's worth in dominant terms, the notion of polynomy made diversity the cornerstone of linguistic identity and value, a perspective in radical opposition to French linguistic ideologies. Corsican speakers were no longer identified as having a "deficit" (a diglossic mentality) but as having an asset - a superior form of sociolinguistic consciousness. It is of some interest, I think, that this discourse appeared as Europeans geared up for 1992, and a European Union which promoted the idea of "unity in diversity." The EU, I think, provided a political and ideological framework which allowed linguistic and cultural minorities to see their "difference" in positive terms that transcended their relationships with a particular nation state. In the Corsican context, this meant that France was no longer the single point of reference for the way that Corsicans defined themselves, and this included sociolinguistic identity.

\section{Issues in the application of polynomy}

As articulated, polynomy presupposes a set of discrete local varieties, all under the ownership of highly competent speakers who identify strongly with those local varieties and

\footnotetext{
${ }^{1}$ for more detail, see Jaffe 1999, Chapter 3.
} 
recognize and acknowledge other speakers like them. The unity in this diversity hinges on 1) personal mastery and identification with clearly-defined local codes and 2) recognition of others' parallel mastery and identification.

It becomes problematic, then, when applied to forms of linguistic diversity that are not clearly bounded or local, and when the competence and authority of speakers cannot be taken for granted. I will argue that both of these complicating conditions are present in Corsica, particularly in schools. Secondly, I will also be exploring the institutional constraints on the implementation of a pluralistic and relativistic notion of linguistic unity in the schools, given their roles as ranking and gatekeeping institutions.

I am drawing here on two sources of data: Ethnographic and experimental. The ethnographic data come from my observation and participation in both a Corsican bilingual school and a bilingual teacher training course. The other source of data comes from student and teacher responses to a Corsican text in which I asked them to circle and correct any spelling errors. The teachers were also asked to identify any words they thought were in "free orthographic variation" - that is, as having more than one possible "correct" spellings. The focus, in both kinds of data, is on the way the idea of a standard for Corsican is represented through linguistic and metalinguistic practice: The extent to which "good Corsican" is represented as authoritative, authoritarian and unitary vs. negotiable, relative and multiple.

\section{SITE ONE: The Teacher Training Course: Tensions of "expert" status}

The bilingual teacher training course that I attended was a form of continuing professional education spanning a whole month, during which all the teachers were released from their classrooms. About a third of the course time was earmarked for groups of teachers to work on developing instructional units in the Corsican language on subjects like Physical Education, Geography or Language Arts. These materials were to be printed and distributed by the Academy. Thus teachers in the existing bilingual classes were treated as agents on the vanguard of change, developing pedagogical materials and practices both for future teachers of fully bilingual classes and for meaningful Corsican language instruction for teachers providing three hours of Corsican language education in non-bilingual classes. Along these lines, course participants were asked to help revise an Academy document that laid out year-by-year student Corsican language performance objectives. Other course content focused on the social and psychological dimensions of bilingualism, on language shift and language policy, as well as demonstrations of communications-based language teaching methods.

While on one level, the course treated all the participants as highly competent Corsican speakers, there were other ways in which their competence was not taken for granted, both by the course organizers and by the participants themselves. For example, one day, the trainer asked all twenty teacher-participants to go around the table and read sections of a Corsican language handout out loud. During the course of the reading, there were noticeable differences in the teachers' level of comfort, confidence and reading fluency, and in some cases, their pronunciations of particular words were actually corrected by the course instructor. The structure of the reading aloud exercise thus did not call upon the participants as expert readers, since they were neither given any choice of what they 
wanted to read nor asked to read in the service of some higher, non-linguistic goal. On the contrary, the exercise was more like a test of their competence, and thus implicitly attributed "student" subject positions to them. These positions were also taken up by some of the teacher participants themselves, who openly discussed problems of their own Corsican language competence and sought out guidance from their more expert peers and from the Academy. It was clear that the challenge of doing their work IN Corsican (language as tool) was far more than a simple passage from one code to another, it was the development of a new set of linguistic rituals and pedagogical practices. One preschool teacher said that she felt lost. "I can't just do [in Corsican] what I do in French," she said.

The educational context of the training course thus threw into relief the fact that not all teachers were coming to the table with a firmly seated sense of linguistic mastery and identity that would allow them, in an ideal "polynomic" world, to negotiate as equals with other competent speakers about what ways of speaking and writing needed to be standardized and taught/tested actively in the classroom vs. left open to both teacher and student choice. On the contrary, even though the pedagogical production part of the course highlighted the absence of official standards for the teaching of Corsican, many participants (particularly those who were new to teaching bilingually or who were linguistically insecure in Corsican) behaved as though there was a single authoritative standard -it was just hidden, elusive, slightly out of their grasp. Less expert practitioners also did not challenge more seasoned teachers' choices of school language. For example, I was party to a conversation in which one teacher was talking about an activity and mentioned that it took place before snacktime. She used the word "vesperinu" for snack. Another teacher looked puzzled, and repeated the word "vesperinu?" with rising intonation. "Le goûter," someone else translated for her into French. The point is, that there is no exact equivalent of the word "goûter" in Corsican, since all the words for small meals also refer to a time of day. "Vesperinu" is thus a possible, but not an obvious Corsican word that could be adapted for "snack". But the tenor of this interaction was that the novice teacher had learned "the" word for snack, not that there was a multiplicity of possible words for snack that teachers could legitimately use in the classroom.

In addition, the standard for polynomic classroom practice was set quite high, and implicitly involved more than "recognition" of other varieties of Corsican. To return to the text that the instructor asked the teacher-participants to read: One of the factors that contributed to their disfluency was that it was written in the instructor's regional variety of Corsican, a variety few if any of his students shared. So in effect, they were being asked not just to acknowledge, but to speak in other voices.

All in all, differences in teachers' competence in Corsican and practice in the bilingual classroom created a sociolinguistic hierarchy in the training course. While there was a good deal of recognition of regional dialectal diversity in the room (almost any conversation included at least one reference to "the way we say it in the region"), diversity of competencies was not recognized, and little space was created for the legitimation of diverse choices in the bilingual classroom (how to talk about snacks being just a small example). 


\section{SITE TWO: A bilingual classroom}

What would it mean to have a polynomic classroom? How could teachers demonstrate the presence and validity of multiple norms? During the school year that I spent in one bilingual school, it seemed to me that the most natural and unproblematic opportunities for displaying unity in diversity were interactional ones: When two Corsican speakers in the class used different linguistic forms. I observed several instance where the teachers I was observing either implicitly legitimated those diverse forms by not mentioning them, or made them an explicit topic of discussion (of the type: "you can say it/write like this, or like this. People from say it this way, people from say it that way"). However, this depended crucially on having people in the classroom who were sufficiently competent speakers of a regionally distinct variety of Corsican. The teachers themselves represented this diversity, since one of them spoke a central variety of Corsican associated with the site of the school, and the other had southern influences in her speech. But for a large part of the school day, the two teachers were separated, teaching in their respective multi-age classrooms, so the bulk of the school interaction in Corsican was between one individual teacher and her students. And here, with respect to language competence and regional identity, out of a student body of 27, there were only 5 speakers with real mastery of Corsican, representing three different dialect areas. While all of these children's language varieties were named and positively recognized by the teachers, they were outnumbered by children whose bilingualism had been acquired almost exclusively at school, and who did not speak any variety of Corsican in the home. As a consequence, the default standard for each classroom became the teacher's variety. This was not because the teachers did not have a polynomic spirit, but because the spirit of polynomy is that people speak and write in their own varieties of Corsican. Outside formal, institutional contexts, this can result in the display/performance of equality. Inside the school, however, the teacher's exercise of a personal relationship with a single variety is not an exchange, but rather, becomes the institutional norm. All school practices related to language treat the teacher's usage as a model or ideal. Children's language productions in class never have the same institutional power and legitimacy as the teacher's; there is simply less space for them to voice their difference. And finally, given the wide disparity in the Corsican competence and dialectal identification of the schoolchildren, few children were able to make use of the spaces that were offered to them to express an alternative linguistic norm.

\section{THIRD BODY OF EVIDENCE: Orthographic evaluations}

Here I turn to the evaluation exercise I gave to two sets of children (11 children between the ages of 8 and 11 in the village school I studied and 10 children aged 10 in a bilingual class in a school in the nearby town) and to 11 bilingual teachers, including the village school teachers whose children participated in the exercise.

Corsican orthography is a particularly productive window on polynomic consciousness for several reasons. First of all, since all orthographies stand for language-assystem, metalinguistic commentary on, debate over and evaluation of specific spellings and/or orthographic principles reveal speakers' ideas about what the system is and where its unity lies. Secondly, orthographies also focalize issues of linguistic authority in their 
display of which form(s) and whose speech is legitimate, and who has evaluative power. Both these issues - the location of unity and authority - are central to an assessment of polynomic consciousness, which defines linguistic system and authority as dispersed and democratic rather than central and authoritarian.

In addition to the general significance of discourse about orthography, there are also some specific dimensions of orthography in Corsican that are salient for the assessment of polynomy. First, there is a long history of often heated debate over how Corsican should be spelled (see Jaffe 1993). In the absence of any kind of recognized language Academy able to impose one official orthography, the orthography debate stands as a conventionalized public discourse used by people to express their views about the nature or the state of the Corsican language. Secondly, while it is true that there is no one official orthography, there is approximately $80-85 \%$ consensus around a wide number of orthographic principles, most of which were outlined in a 1971 manual called Intricciate e Cambiarine. This manual can be seen as one of the earliest polynomic documents, because it does not impose a single spelling for every word, but rather, outlines a series of principles through which speakers of different regional dialects can represent the way that they speak. So the word for "ours" is spelled "nosciu" for those speakers who pronounce it [nošu] and "nostru" for those who say it [nostru]. The person who says [pàrtimu] for "let's go" will write "partimu"; the person who says [pÀrtÅmu] will write it "partemu." There is, however, only one grapheme for any possible sound in Corsican, and there are unified norms for representing the lenition of intervocalic consonants that characterizes most (though not all) Corsican dialects. In sum, the system itself allows for, but does not prescribe practices that are polynomic in nature.

The question then was, to what extent did teachers take up a polynomic position with respect to Corsican spelling? Did they convey a respect for multiple standards of spelling (and the language varieties they indexed) either actively or passively in the way that they taught Corsican literacy or evaluated student writing? What did schoolchildren absorb about the existence and validity of multiple orthographic norms? One of the research strategies I used to answer these questions was to create a one-paragraph text that exhibited a wide range of orthographic variants. These included violations of what I judged to be the de facto standard for a) the graphic display of grammatical categories or syllabic stress through accents and gender/number concordance and b) spellings of particular sounds, including rules for the representation of the consonants that were subject to lenition (the "cambiarine," or "changers" of the 1971 manual's title). ${ }^{2}$ Other variants I planted in the text related directly to dialectal variation in the pronunciation of words. The text also included orthographic variants that were simply a matter of personal esthetic preference, and did not reflect any differences in grammar or pronunciation. Figure 1 represents the text as it appeared to the children, followed by a translation. Figure 2 reproduces the text with a (partial) interlinear gloss which makes visible issues of agreement. This is followed by a detailed key to orthographic variants that are boldfaced, underlined and organized into three categories (see numbers in parentheses).

\footnotetext{
${ }^{2}$ My thanks to Pascal Ottavy, a Corsican linguist with whom I checked my assumptions.
} 


\section{FIGURE 1:}

Testu: Inturnia i sbagli. Metti a parolla ghjusta sottu.

Mercuri (1) scorsu, a mo amiga Anghjula Maria hè andata a fà i spesi (1)in Bastia, perchè un c'era(2) micca scola. Ella hè falatu cù a so mamma è u so babbu. Vulia anch'eiu accumpagnalla (2), ma ùn avia più soldi perche aghju cumpratu (1) un rigalu per(2) l'anniversariu di u mo fradellu (ghjè u 25 di ghjunghju (1). Aghju compru(1) un discu di cansone zittellina "Girascola". A mo canzona preferita si chjama "Un stà à sente". Si parla di jente (3) di culori sfarenti, e di u prublema di u razisimu. Anghjula Maria hè un' amica rava, perchè m'a datu centu franchi. Sabatu (1) chì vene, li rendu i so soldi e partimu(1) inseme be manghjà una pizza in città(1), induve c'hè(2) un ristorante chì si chjama "L'Alifante". A pizza, avemu à manghjà la (2) vora-à u mese di ghjugnu (1), hà digià cumminciattu à fà bellu tempu, e si mette e tavule à nantu a strada. Emu à beie una bouttiglia (3) di Coca Cola incù a nostra pizza!

Text:

Circle the errors. Put the correct word below.

Last Wednesday, my friend Angela Maria went shopping in Bastia, because there was no school. She went down with her mother and her father. I wanted to go with her too, but I didn't have any more money because I had bought a present for my brother's birthday (it's the $25^{\text {th }}$ of June. I bought a CD of children's songs called "Girascola". My favorite song is called "Don't Listen." It talks about people of different colors and the problem of racism. Angela Marie is a good friend, because she gave me 100 francs. Next Saturday, I will return her money and we'll go together to eat a pizza in town, where there is a restaurant called "The Elephant". The pizza, we'll eat it outside - in June it has already started to be nice outside, and they put the tables out on the street. We'll drink a bottle of Coke with our pizza!

FIGURE 2

Testu: Inturnia i sbagli.

Text: Circle the(masc.pl.) errors (masc.pl.).

Circle the errors

Metti a parolla ghjusta sottu.

Put the(fem.sing.) word(fem.sing.) correct below

Put the correct word below

(1) Mercuri (1) scorsu, a mo amiga Anghjula Maria hè

Wednesday last my (fem.sing.)triend Angela Maria is

Last Wednesday, my friend Angela Maria

(2) andata

a $\mathrm{f}_{\grave{a}} \mathrm{i}$

spesi(1)

in Bastia, perchè un went (fem.sing.) to do the(masc.pl.) shopping(masc.pl.) in Bastia, because neg. went shopping in Bastia, because

(3) c'era(2) micca scola. Ella hè falatu it was neg. school. she is

$\mathrm{c}_{\grave{u}}$ a so went down (masc.sing.) with her(fem.sing.) 
there was no school. She went down with her

(4) mamma ì u so babbu.

mother(fem.sing.) and her(masc.sing.) father (masc.sing.)

mother and her father.

(5) Vulia anch'eiu (2), accumpagnalla ma un avia pi ̀̀ soldi wanted also I to accompany her but neg had any more money

I wanted to go with her too, but I didn't have any more money

(6) perche aghju cumpratu (1) un rigalu per(2) l'anniversariu di because I have bought a present for the birthday of

because I had bought a present for my brother's birthday

(7) u mo fradellu (ghjè u 25 di ghjunghju). (1) Aghju compru(1) my brother (it is the 25 of June) I have bought

(it's the 25th of June). I bought

(8) un discu di cansone zittellina "Girascola". a CD of songs (fem.pl.) childhood (fem.sing.)"Girascola"

a CD of children's songs called "Girascola"

(9) A mo canzona preferita si chjama "Un stà à sente". my song(fem.sing.) preferred (fem.sing.)itself calls "neg.listen"

My favorite song is called "Don't Listen."

(10)Si parla di jente(3) di culori sfarenti, itself speaks of people of colors(masc.pl.) different (masc.pl.)

It talks about people of different colors

(11) $\underline{\mathrm{e}} \mathrm{di} \mathrm{u}$ and of prublema $_{\text {the(masc.sing.) }}$ di u problem $\frac{\text { razisimu. }}{\text { (masc.sing.) of the(masc.sing.) }}$ racism(masc.sing.)

and the problem of racism.

(12)Anghjula Marịa hè un’amica rava, , perchè Angela Marie is a friend (fem.sing.) good'(fem.sing.) because

Angela Marie is a good friend, because

(13)m' a datu centu franchi. Sabatu (1) chi vene li rendu me has gave hundred francs. Saturday that is coming her I return she gave me 100 francs. Next Saturday, I will return

(14)i so soldi $\frac{\mathrm{e}}{\mathrm{p}}$ partimu(1)inseme be manghj her monies (masc.pl.) and we leave together to eat back her money and we'll go together to eat

(15)una pizza in città(1), induve c'hè(2) un ristorante $\mathrm{ch}_{i}$ si a pizza in city where it is a restaurant that itself 
a pizza in town, where there is a restaurant

(16)chjama "L'Alifante". A pizza, a avemu à manghjà la (2)

calls "the elephant" the pizza(fem.sing.), we have to eat

it(fem.sing.)

called "The Elephant". The pizza, we'll eat it

(17)vora- à u mese di ghjugnu (1), hà digi ̀̀ cumminciattu outside-at the month of June it has already begun

outside -in June it has already started outside -in June it has already started

(18) à $\mathrm{f}_{\grave{a}}$ bellu tempu, e si mette ${ }^{3}$ e tavule à nantu a strada.

to make good weather and itself places the tables on $\frac{}{\text { the street. }}$

to be nice outside, and they put the tables out on the street.

(19)Emu à beie una bouttiglia (3) di Coca Cola inc ̀̀ a nostra pizza! we have to drink a bottle (fem.sing) of Coca Cola with our(fem.sing.)pizza!

We'll drink a bottle of Coke with our pizza!

KEY : numbers in parentheses following a boldfaced word indicate the following:

(1) spellings that reflect alternate pronunciations or grammatical forms heard in the bilingual school I observed, and in the region (central). Mercuri/Marcuri; i spesi/e spese; ghjungnu/ghjunghju; sabatu/sabbatu; partimu/partemu; città/cità; alifante/elifante.

(2) non-grammatical, non-phonetic variants. c'era/ci era; accumpagnalla/accumpagnà la; cumpratu/compru; per/pè; c'hè/ci hè; manghjà la/manghjalla

(3) examples of transfer from French orthographic norms. The use of the trigraph ghj to represent the sound [dj] that begins the word for "people" is one of the emblematic symbols of Corsican orthography. 20 years ago, there was considerable debate between those who favored writing this sound with the closed orthographic equivalent from Italian or French ("j") but today, the use of "ghj" is used by almost $100 \%$ of Corsican writers. In the case of the word for "bottle," the issue is the sound $[u]$, written "ou" in French and "u" in Corsican. Again, this has almost 100\% consensus.

Underlined: "errors" of concord (subject-verb and noun-adjective), of pan-Corsican pronunciation, and of accent placement [a) grammatical--on infinitives, prepositions, on words like "and" ("è) to distinguish it from "e" the fem. pl. art. and b) on stressed syllables, for pronunciation purposes].

Some examples:

- "friend" conventionally spelled "amica"; pronounced [amiga].

- "good friend" conventionally spelled "amica brava"; pronounced [amiga rava].

- "racism" is pronunced universally as [ratsizimu]. [ts] is conventionally represented with double

"zz" while a single "z" should be pronounced $[\mathrm{z}]$.

- "because" is missing an accent on the end. In conventional usage "perche" should be "perchè".

- "for" is either missing an accent or a following "r". In conventional usage, "pe" should thus be either "pè" or "per".

- "children's songs": "songs" is fem. pl. and thus the adjective requires a fem.pl. ending "e". Thus "canzone zittelina" should be "canzone zitteline".

3 this verb should be "mettenu," in order to agree with the number of "tables". It was an inadvertent error on my part, and was not noticed by anyone who evaluated the text. 
I gave slightly different directions to teachers and children. I asked the children to circle any errors they saw in the text and to indicate the correct spelling somewhere on the page. I asked the teachers to circle the errors they would want a 5th or 6th grader to identify, write the correct responses, and also to tell me what words they though were in orthographic "free variation" - that is, which had more than one correct spelling. For the teachers, this evaluation task was very close to the correcting of student papers that they did as a regular part of their professional practice. For the students, the task was also part of their repertoire of school practice (albeit a much smaller part) as most students had been exposed - if not frequently - to the "find the errors" category of exercise. As a methodological note, I regret not having asked the children to identify specifically those words they though might have multiple norms. It also must be noted that the way that I set up the exercise presupposed that there were some "mistakes" on the page, making it unlikely for any respondent to tell me the whole text was acceptable.

Table 1 shows how many times individual words in the text were circled by the three sets of respondents, and what, if any, "correct" alternatives they proposed. Under the teachers' column, it also indicates those words in the text that the teachers considered in free orthographic variation.

TABLE 1: Summary of Words Circled and Alternatives Proposed (number of times a given alternative is proposed indicated by number in parentheses)

\begin{tabular}{|l|l|l|l|l|}
\hline Word circled & $\begin{array}{l}\text { alternatives } \\
\text { proposed by } \\
\text { town class }\end{array}$ & $\begin{array}{l}\text { alternatives } \\
\text { proposed by } \\
\text { village class }\end{array}$ & $\begin{array}{l}\text { alternatives proposed by } \\
\text { teachers }\end{array}$ & $\begin{array}{l}\text { total \# } \\
\text { times } \\
\text { circled }\end{array}$ \\
\hline $\begin{array}{l}\text { inturnia } \\
\text { circle }\end{array}$ & & & inturniighja & 1 \\
\hline $\begin{array}{l}\text { Mercuri } \\
\text { Wednesday }\end{array}$ & corsu & free variation (4) & 0 \\
\hline $\begin{array}{l}\text { scorsu } \\
\text { last }\end{array}$ & & $\begin{array}{l}\text { mo (2) } \\
\text { miò (1) } \\
\text { mio (2) }\end{array}$ & $\begin{array}{l}\text { mio (1) } \\
\text { free variation (1) }\end{array}$ & 0 \\
\hline $\begin{array}{l}\text { mo } \\
\text { my }\end{array}$ & $\begin{array}{l}\text { amica (3) } \\
\text { amicha (1) }\end{array}$ & $\begin{array}{l}\text { amica (6) } \\
\text { no alt. (1) }\end{array}$ & 7 \\
\hline $\begin{array}{l}\text { amiga } \\
\text { friend }\end{array}$ & amica (10) & $\begin{array}{l}\text { à (4) } \\
\text { the "a" circled, no alt (1) }\end{array}$ & 5 \\
\hline $\begin{array}{l}\text { andata a } \\
\text { went to }\end{array}$ & & free variation (1) & 1 \\
\hline $\begin{array}{l}\text { perchè } \\
\text { because }\end{array}$ & $\begin{array}{l}\text { e alt. (4) } \\
\text { e spese (2) } \\
\text { shopping } \\
\text { pesi (1) }\end{array}$ & e spese (1) & $\begin{array}{l}\text { e spese (4) } \\
\text { circled and underlined (1) } \\
\text { "i" and "i" circled (1) }\end{array}$ & 15 \\
\hline $\begin{array}{l}\text { un } \\
\text { neg. }\end{array}$ & & ci era (1) & ùn (4) & (1) \\
\hline $\begin{array}{l}\text { avia } \\
\text { had (imperfect) }\end{array}$ & & & aviu (1) & 1 \\
\hline $\begin{array}{l}\text { c'era } \\
\text { there was }\end{array}$ & & & & 4 \\
\hline
\end{tabular}




\begin{tabular}{|c|c|c|c|c|}
\hline $\begin{array}{l}\text { falatu } \\
\text { went down } \\
\text { (m.sing) }\end{array}$ & $\begin{array}{l}\text { falata (8) } \\
\text { falate (1) } \\
\text { no alt. (1) }\end{array}$ & $\begin{array}{l}\text { falata (6) } \\
\text { faladu (2) } \\
\text { falatù (1) }\end{array}$ & $\begin{array}{l}\text { falata }(8) \\
\text { no alt. (2) }\end{array}$ & 29 \\
\hline $\begin{array}{l}\text { babbu } \\
\text { father }\end{array}$ & & & free variation (1) & 0 \\
\hline $\begin{array}{l}\text { accumpagnalla } \\
\text { accompany her }\end{array}$ & & & $\begin{array}{l}\text { free variation (1) } \\
\text { "la" circled (1) } \\
\text { accumpagna la (2) }\end{array}$ & 3 \\
\hline $\begin{array}{l}\text { soldi } \\
\text { money }\end{array}$ & & & free variation (1) & 0 \\
\hline $\begin{array}{l}\text { perche } \\
\text { because }\end{array}$ & & perchè (1) & $\begin{array}{l}\text { perchè }(8) \\
\text { free variation }(2)\end{array}$ & 11 \\
\hline $\begin{array}{l}\text { aghju cumpratu } \\
\text { I bought }\end{array}$ & & & $\begin{array}{l}\text { free variation (2) } \\
\text { "atu" circled (1) }\end{array}$ & 1 \\
\hline $\begin{array}{l}\text { aghju } \\
\text { I have }\end{array}$ & & avia (1) & & 1 \\
\hline $\begin{array}{l}\text { compru } \\
\text { bought }\end{array}$ & & & free variation (1) & 0 \\
\hline $\begin{array}{l}\text { per } \\
\text { for }\end{array}$ & & & free variation (1) & 0 \\
\hline $\begin{array}{l}\text { fradellu } \\
\text { brother }\end{array}$ & fratellu (10) & fratellu (3) & $\begin{array}{l}\text { fratellu (6) } \\
\text { no alt. (2) } \\
\text { fratellu or frateddu (1) }\end{array}$ & 22 \\
\hline $\begin{array}{l}\text { ghjunghju } \\
\text { June }\end{array}$ & $\begin{array}{l}\text { ghjungnu (8) } \\
\text { ghjunghjnu (1) } \\
\text { no alt. (1) }\end{array}$ & $\begin{array}{l}\text { ghjungnu (5) } \\
\text { ghjunghjnu (1) }\end{array}$ & $\begin{array}{l}\text { free variation (3) } \\
\text { one beginning of circle then } \\
\text { crossed out (?) } \\
\text { ghjungnu (2) } \\
\text { ghjughju (1) }\end{array}$ & 22 \\
\hline $\begin{array}{l}\text { compru } \\
\text { bought }\end{array}$ & & comprù (1) & free variation (1) & 1 \\
\hline $\begin{array}{l}\text { cansone } \\
\text { song }\end{array}$ & & $\begin{array}{l}\text { canzone (3) } \\
\text { canssone (1) }\end{array}$ & $\begin{array}{l}\text { canzone (8) } \\
\text { free variation (1) } \\
\text { no alt. (1) }\end{array}$ & 13 \\
\hline $\begin{array}{l}\text { preferita } \\
\text { favorite (f.sing) }\end{array}$ & & & free var. ("i" poss) (1) & 0 \\
\hline $\begin{array}{l}\text { zittellina } \\
\text { childhood }\end{array}$ & & $\begin{array}{l}\text { zitelline (2) } \\
\text { zitellina (2) }\end{array}$ & $\begin{array}{l}\text { zitelline (7) } \\
\text { no alt. (1) } \\
\text { zitiddini (1) }\end{array}$ & 13 \\
\hline $\begin{array}{l}\text { mo } \\
m y\end{array}$ & & $\begin{array}{l}\text { mò }(2) \\
\text { mio (1) }\end{array}$ & $\begin{array}{l}\text { mio (1) } \\
\text { free variation (1) }\end{array}$ & 4 \\
\hline $\begin{array}{l}\text { preferita } \\
\text { preferred }(f . \text { sing })\end{array}$ & & preferatu (1) & & 1 \\
\hline $\begin{array}{l}\text { si chjama } \\
\text { is called }\end{array}$ & & & "si" circled, accent added? & 1 \\
\hline $\begin{array}{l}\text { "Un sta..." } \\
\text { do not be }\end{array}$ & & & $\begin{array}{l}\text { Un sta...(2) } \\
\text { "U" circled (1) }\end{array}$ & 3 \\
\hline $\begin{array}{l}\text { sente } \\
\text { listen }\end{array}$ & & & free variation & 0 \\
\hline $\begin{array}{l}\text { jente } \\
\text { people }\end{array}$ & $\begin{array}{l}\text { ghente (3) } \\
\text { jenti (2) } \\
\text { jinti (2) } \\
\text { gente (2) } \\
\text { no alt. (2) }\end{array}$ & ghjente (5) & $\begin{array}{l}\text { ghjente (7) } \\
?(1) \\
\text { free variation (1) } \\
\text { no alt. (1) }\end{array}$ & 25 \\
\hline
\end{tabular}


“Polynomic" language, expert statuses and orthographic practices in Corsican schools

\begin{tabular}{|c|c|c|c|c|}
\hline $\begin{array}{l}\text { culori } \\
\text { colors }\end{array}$ & & & free variation (1) & 0 \\
\hline $\begin{array}{l}\mathrm{e} \\
\text { and }\end{array}$ & & & $\begin{array}{l}\text { è (4) } \\
\text { no alt. (2) }\end{array}$ & 6 \\
\hline $\begin{array}{l}\text { prublema } \\
\text { problem }\end{array}$ & & prublemu (2) & "a" circled then crossed out & 3 \\
\hline $\begin{array}{l}\text { razisimu } \\
\text { racism }\end{array}$ & & razzisimu (3) & $\begin{array}{l}\text { razzisimu (3) } \\
\text { no alt. (2) }\end{array}$ & 8 \\
\hline $\begin{array}{l}\text { un' amica } \\
\text { a friend }(f . \text { sing })\end{array}$ & & & no alt. & 1 \\
\hline $\begin{array}{l}\text { rava } \\
\text { nice }\end{array}$ & $\begin{array}{l}\text { brava }(5) \\
\text { no alt. }(4) \\
\text { ravà }(1)\end{array}$ & brava (6) & $\begin{array}{l}\text { brava (9) } \\
\text { no alt. (1) }\end{array}$ & 26 \\
\hline $\begin{array}{l}\text { m'a } \\
\text { had [to me] }\end{array}$ & & & $\begin{array}{l}\text { m'hà (7) } \\
\text { no alt. (2) }\end{array}$ & 9 \\
\hline $\begin{array}{l}\mathrm{e} \\
\text { and }\end{array}$ & & & $\begin{array}{l}\text { è }(2) \\
\text { no alt. (1) }\end{array}$ & 3 \\
\hline $\begin{array}{l}\text { partimu } \\
\text { we leave }\end{array}$ & & & free variation (1) & 0 \\
\hline $\begin{array}{l}\text { Sabatu } \\
\text { Saturday }\end{array}$ & $\begin{array}{l}\text { Sabbatu (6) } \\
\text { Sabàtu (2) } \\
\text { sabattu (1) } \\
\text { sabbatu(1) }\end{array}$ & Sabbatu (7) & $\begin{array}{l}\text { free variation (4) } \\
\text { no alt. (1) } \\
\text { Sabbatu (1) }\end{array}$ & 23 \\
\hline $\begin{array}{l}\text { vene } \\
\text { comes }\end{array}$ & & & free variation (1) & 0 \\
\hline $\begin{array}{l}\mathrm{e} \\
\text { and }\end{array}$ & & & $\begin{array}{l}\text { è (4) } \\
\text { no alt. (1) }\end{array}$ & 5 \\
\hline $\begin{array}{l}\text { inseme } \\
\text { together }\end{array}$ & & & free variation (1) & \\
\hline $\begin{array}{l}\text { be } \\
\text { to;for; in order to }\end{array}$ & $\begin{array}{l}\text { pè }(3) \\
\text { no alt. (3) } \\
\text { bè }(2) \\
\text { per }(1) \\
\text { bé }(1)\end{array}$ & pè (4) & $\begin{array}{l}\text { pè }(4) \\
\text { par }(1) \\
\text { pè or per }(2) \\
\text { per }(2) \\
\text { no alt }(1)\end{array}$ & 24 \\
\hline $\begin{array}{l}\text { in città } \\
\text { in town }\end{array}$ & $\begin{array}{l}\text { cità (7) } \\
\text { cita (3) }\end{array}$ & $\begin{array}{l}\text { in a città }(1) \\
\text { cità }(3)\end{array}$ & $\begin{array}{l}\text { cità (3) } \\
\text { free variation (1) } \\
\text { no alt. (1) }\end{array}$ & 19 \\
\hline $\begin{array}{l}\text { induve } \\
\text { where }\end{array}$ & & & free variation (1) & 0 \\
\hline $\begin{array}{l}\text { ristorante } \\
\text { restaurant }\end{array}$ & & $\begin{array}{l}\text { ristorente (2) } \\
\text { risturente (1) }\end{array}$ & free variation (1) & 3 \\
\hline $\begin{array}{l}\text { l'Alifante } \\
\text { The Elephant }\end{array}$ & & l'alifantu (1) & $\begin{array}{l}\text { free variation (2) } \\
\text { no alt. (1) }\end{array}$ & 4 \\
\hline $\begin{array}{l}\text { avemu à } \\
\text { we are going to }\end{array}$ & & & $\begin{array}{l}\text { avemu da (5) } \\
\text { no alt. (1) } \\
\text { avemu dà (1) }\end{array}$ & 7 \\
\hline $\begin{array}{l}\text { manghà la } \\
\text { to eat it }\end{array}$ & & & free variation (2) & 0 \\
\hline $\begin{array}{l}\text { vora } \\
\text { outside }\end{array}$ & $\begin{array}{l}\text { fora }(7) \\
\text { no alt. }(2) \\
\text { bora }(1) \\
\end{array}$ & fora (2) & $\begin{array}{l}\text { fora (8) } \\
\text { no alt. (1) }\end{array}$ & 21 \\
\hline $\begin{array}{l}\text { mese } \\
\text { month }\end{array}$ & & & free variation (1) & 0 \\
\hline
\end{tabular}




\begin{tabular}{|c|c|c|c|c|}
\hline $\begin{array}{l}\text { ghjugnu } \\
\text { June }\end{array}$ & & ghjungnu (1) & $\begin{array}{l}\text { free variation (1) } \\
\text { no alt. (1) }\end{array}$ & 2 \\
\hline $\begin{array}{l}\text { digià } \\
\text { already }\end{array}$ & & & free variation & \\
\hline $\begin{array}{l}\text { cumminciattu } \\
\text { begun }\end{array}$ & & cumminciatu (2) & $\begin{array}{l}\text { cumminciatu (7) } \\
\text { cuminciatu (2) } \\
\text { no alt. (1) }\end{array}$ & 12 \\
\hline $\begin{array}{l}\text { bellu } \\
\text { beautiful }\end{array}$ & & & free variation (1) & \\
\hline $\begin{array}{l}\mathrm{e} \\
\text { and }\end{array}$ & & & $\begin{array}{l}\mathrm{è}(6) \\
\text { no alt. (1) }\end{array}$ & 7 \\
\hline $\begin{array}{l}\text { si mette } \\
\text { place self }\end{array}$ & & & free variation (1) & 0 \\
\hline $\begin{array}{l}\text { tavule } \\
\text { tables }\end{array}$ & & $\begin{array}{l}\text { tavulle (1) } \\
\text { tavulelli (1) } \\
\text { tavula (1) } \\
\end{array}$ & $\begin{array}{l}\text { i tavulini (2) } \\
\text { no alt. (1) } \\
\text { free variation (1) }\end{array}$ & 6 \\
\hline $\begin{array}{l}\text { à nantu a strada } \\
\text { on the street }\end{array}$ & & & $\begin{array}{l}\text { à nantu à a strada (3) } \\
\text { à nanta à strada (1) } \\
\text { nantu à a strada (1) }\end{array}$ & 5 \\
\hline $\begin{array}{l}\text { Emu à } \\
\text { we had to }\end{array}$ & $\begin{array}{l}\text { no alt. (6) } \\
\text { Eiu (1) } \\
\text { Ému (1) } \\
\text { Ema (1) }\end{array}$ & emu dà (1) & $\begin{array}{l}\text { Emu da (5) } \\
\text { Avemu à (1) } \\
\text { Emu dà (1) } \\
\text { no alt. (1) }\end{array}$ & 19 \\
\hline $\begin{array}{l}\text { beie } \\
\text { to drink }\end{array}$ & no alt. (1) & & free variation (1) & 1 \\
\hline $\begin{array}{l}\text { bouttiglia } \\
\text { bottle }\end{array}$ & $\begin{array}{l}\text { no alt. (4) } \\
\text { buttiglia (2) } \\
\text { bouttilia (1) } \\
\text { boutiglia (1) } \\
\text { bouttigia (1) }\end{array}$ & buttiglia (1) & $\begin{array}{l}\text { buttiglia (9) } \\
\text { no alt. (1) }\end{array}$ & 20 \\
\hline $\begin{array}{l}\text { incù } \\
\text { with }\end{array}$ & & $\begin{array}{l}\text { ancù (1) } \\
\text { in cù (1) }\end{array}$ & & 2 \\
\hline $\begin{array}{l}\text { nostra } \\
\text { our }\end{array}$ & & & free variation & 0 \\
\hline
\end{tabular}

\section{General comments}

Of note is that out of 245 total mentions of words in the text, 200 (approximately 80\%) identify errors and 45 (approximately 20\%) indicate one or more alternative spellings. Moreover, one teacher was responsible for over half of those 45 "free variation" notations. What is interesting here is that through one or two of his proposed alternatives, he identified himself as a "southern" speaker, and most of the words he underlined reflected Northern or Central pronunciations that contrasted with alternative pronunciations in the South. This throws into relief that the text was in fact distinctly non-Southern, since I originally designed it for use in a single Central/Northern school that I had observed for several months, and had wanted to only include the kind of spoken and written variation that the children encountered in the classroom. Two things are worth noting here. First is that my text in itself shows the narrow range of the regional dialectal variation that was displayed in the school I observed, and that they had not been systematically exposed to Southern 
texts and speech. From observations of other elementary classes in this region, I can say that this was a widespread pattern; it is not until middle school that children get explicit instruction about regional dialectal variation (and this depends somewhat on the teacher). Thus my own instrument design reveals something about polynomy, which is that it does not "just happen" naturally or spontaneously: It has to be an active, pedagogical agenda. Few teachers engaged in teaching Corsican to children who do not speak the language well or at all put the issue of variation high on their agendas. The second significant observation concerns the teachers' responses: There was not a single Central/Northern-speaking teacher who indicated any possible Southern spellings. This was true despite the fact that the text contained the word for "brother," an exceptionally common noun that exhibits the most widely recognized North-South pronunciation difference: "fratellu" in the North and "frateddu" in the South. While I did not interview all the teachers who filled out this survey, other teacher interviews and my experiences with teachers in a variety of professional contacts leads me to believe that Northern/Central-speaking teachers would have explicitly acknowledged Southern forms as legitimate if they had been asked explicitly about dialectal variation. But this kind of polynomic consciousness at the level of metalinguistic discourse was not activated by the task I set them: A very academic exercise: One in which evaluation was foregrounded and, to return to my earlier point, one in which they were not put into contact or interaction with competent speakers of another variety of Corsican than their own. In this context, which typifies what goes on in school, polynomy remains rather virtual and latent.

\section{Specific categories of orthographic variation}

If we look more closely at the spellings that were identified as errors, one general result that emerges from this data is that both teachers and students were very attentive to the orthographic representation of the "cambiarine": Corsican consonants and consonant blends subject to lenition in intervocalic contexts. The text had 6 words in which I had spelled these consonants phonetically rather than phonemically (see Table 2). The cambiarine are highly salient markers of Corsican literacy, and they get a great deal of attention in the classroom because teachers are very concerned to prevent their students from having "spelling pronunciations" (based on French orthographic norms) that would label them as inauthentic Corsican speakers. In the classroom that I observed most intensively, I saw many instances of teacher corrections of "cambiarine" mistakes in both spelling and pronunciation. The students' consciousness of the cambiarine was also evidenced in the nature of their hypercorrections when reading out loud. For example, a child reading the word "pulitu" [clean] at the beginning of a sentence might pronounce it [bulidu], softening both the $/ \mathrm{p} /$ and the $/ \mathrm{t} /$, whereas only the $/ \mathrm{t} /$ was in an intervocalic context requiring that lenition. The overgeneralization, then, was that Corsican consonants were not to be pronounced the way they "looked" - where the sound-to-grapheme relationship was normed on French. 
Table 2: "Cambiarine"

\begin{tabular}{|c|c|c|c|c|}
\hline $\begin{array}{l}\text { word circled, } \\
\text { followed by } \\
\text { alternative } \\
\text { proposed---> }\end{array}$ & $\begin{array}{l}\text { by town class } \\
(\mathrm{n}=10)\end{array}$ & $\begin{array}{l}\text { by village class } \\
(\mathrm{n}=11)\end{array}$ & by teachers $(\mathrm{n}=11)$ & $\begin{array}{l}\text { total } \\
\text { times } \\
\text { word } \\
\text { circled } \\
\end{array}$ \\
\hline $\begin{array}{l}\text { amiga } \\
\text { friend (fem.) }\end{array}$ & amica (10) & $\begin{array}{l}\text { amica (3) } \\
\text { amicha (1) }\end{array}$ & $\begin{array}{l}\text { amica (6) } \\
\text { no alt. (1) }\end{array}$ & 21 \\
\hline $\begin{array}{l}\text { falatu } \\
\text { went down } \\
\text { (masc.sing.p.p.) } \\
\end{array}$ & $\begin{array}{l}\text { falata }(8) \\
\text { falate }(1) \\
\text { no alt. }(1) \\
\end{array}$ & $\begin{array}{l}\text { falata }(6) \\
\text { faladu (2) } \\
\text { falatù (1) } \\
\end{array}$ & $\begin{array}{l}\text { falata (8) } \\
\text { no alt. (2) }\end{array}$ & 29 \\
\hline $\begin{array}{l}\text { fradellu } \\
\text { brother }\end{array}$ & fratellu (10) & fratellu (3) & $\begin{array}{l}\text { fratellu (6) } \\
\text { no alt. (2) } \\
\text { fratellu or frateddu (1) }\end{array}$ & 22 \\
\hline $\begin{array}{l}\text { rava } \\
\text { good }\end{array}$ & $\begin{array}{l}\text { brava }(5) \\
\text { no alt. }(4) \\
\text { ravà }(1) \\
\end{array}$ & brava (6) & $\begin{array}{l}\text { brava (9) } \\
\text { no alt. (1) }\end{array}$ & 26 \\
\hline $\begin{array}{l}\text { cansone } \\
\text { song }\end{array}$ & & $\begin{array}{l}\text { canzone (3) } \\
\text { canssone (1) }\end{array}$ & $\begin{array}{l}\text { canzone (8) } \\
\text { free variation (1) } \\
\text { no alt. (1) } \\
\end{array}$ & 13 \\
\hline $\begin{array}{l}\text { be } \\
\text { to;for; in order to }\end{array}$ & $\begin{array}{l}\text { pè }(3) \\
\text { no alt. (3) } \\
\text { bè }(2) \\
\text { per }(1) \\
\text { bé }(1)\end{array}$ & pè (4) & $\begin{array}{l}\text { pè }(4) \\
\text { par }(1) \\
\text { pè or per }(2) \\
\text { per }(2) \\
\text { no alt }(1)\end{array}$ & 24 \\
\hline $\begin{array}{l}\text { vora } \\
\text { outside }\end{array}$ & $\begin{array}{l}\text { fora (7) } \\
\text { no alt. (2) } \\
\text { bora (1) }\end{array}$ & fora (2) & $\begin{array}{l}\text { fora (8) } \\
\text { no alt. (1) }\end{array}$ & 21 \\
\hline
\end{tabular}

Both teachers and students were sensitive to concord (Table 3, below), although fewer students than teachers noticed that "zittellina" (fem. sing.) did not agree with the noun "cansone" (fem. pl.), probably because there are some singular nouns in Corsican that end in "e". The disaccord between the fem. sing. subject and the past participle "falatu" (masc. sing.) was noticed by almost everyone. There are several factors that I think explain these results. First, concord is something that is heavily stressed in the teaching of both Corsican and French. Moreover, in the variety of Corsican spoken in the respondents' schools, concord is always audible in Corsican ${ }^{4}$ (whereas it is not in French), which meant that students could draw on their listening as well as their oral competence in order to perform the spelling task.

${ }^{4}$ In Northern/Central varieties, the masculine singular always ends in $-\mathrm{u}$, and the masculine plural in $-\mathrm{i}$. The feminine singular ending is $-\mathrm{a}$ and the plural, -e. In Southern varieties of Corsican, there are masculine plurals in both $-\mathrm{i}$ and $-\mathrm{e}$, as well as feminine singulars in $-\mathrm{i}$. 
Table 3: Concord

\begin{tabular}{|c|c|c|c|c|}
\hline $\begin{array}{l}\text { word circled, } \\
\text { followed by } \\
\text { alternative } \\
\text { proposed---> }\end{array}$ & $\begin{array}{l}\text { by town class } \\
(\mathrm{n}=10)\end{array}$ & $\begin{array}{l}\text { by village class } \\
(\mathrm{n}=11)\end{array}$ & by teachers $(n=11)$ & \begin{tabular}{|l|} 
total \\
times \\
word \\
circled \\
\end{tabular} \\
\hline $\begin{array}{l}\text { falatu } \\
\text { went down } \\
\text { (masc.sing.p.p.) }\end{array}$ & $\begin{array}{l}\text { falata (8) } \\
\text { falate (1) } \\
\text { no alt. (1) }\end{array}$ & \begin{tabular}{|l|} 
falata (6) \\
faladu (2) \\
falatù (1) \\
\end{tabular} & $\begin{array}{l}\text { falata (8) } \\
\text { no alt. (2) }\end{array}$ & 29 \\
\hline $\begin{array}{l}\text { zittellina } \\
\text { childhood } \\
\text { (fem.sing.) } \\
\end{array}$ & & \begin{tabular}{|l} 
zitelline (2) \\
zitellina (2)
\end{tabular} & $\begin{array}{l}\text { zitelline (7) } \\
\text { no alt. (1) } \\
\text { zitiddini (1) } \\
\end{array}$ & 13 \\
\hline
\end{tabular}

Student and teacher respondents also exhibited agreement in their judgments of spellings derived from language contact with French, depicted in Table 4 below. The examples in the table are of slightly different orders, since "bouttiglia" ("bottle") and "jente" ("people") have to do with sound-spelling relationships only, while "emu à" and "avemu à" (both meaning 'we are going to') also involve grammar. While the preposition "to" only has one form in French, "à"; in Corsican it is spelled "da" following an auxiliary verb (as in, "I have to run," or "I'm going to do it"). In all other cases, the preposition "to" is spelled " à" in Corsican. The [d] in the word "da" is only pronounced at the beginning of a sentence or other phrase unit. ${ }^{5}$ Statistically, "da" occurs more often in an intervocalic context and as a consequence is heard most often as [a]. In French, there is only one word for both of these functions: "à". This explains, I think, the lesser frequency with which both teachers and children (though children even less than teachers) circled "avemu à" and "Emu à". We can also see that "Emu à" was circled over twice as often as "avemu à". I suspect that this is because the use of "Emu" was a graphic attention-getter, both because it was at the beginning of a sentence and therefore capitalized, and (which was my motivation for including it in the text) because "emu" is a casual pronunciation of "we have" which is less often represented in writing than the full verb form.

Of greater interest to the issue of polynomy is the spelling of "people," because it involves a trigraph (--ghj) which is a potent symbol of Corsican orthographic differentiation from both French and Italian. Twenty years ago, there was considerable disagreement over whether the sound [dy] in Corsican should be spelled with "j" or "g" - the way its closest sound equivalents were spelled in French and Italian respectively. Proponents of the trigraph emphasized that the sound was a unique feature of Corsican phonetics, and shouldn't be rendered by an approximation from other phonetic repertoires. Proponents of the " $j$ " emphasized Corsican's linguistic relationship to Italian, or argued that it was "easier" to learn to spell the language using French conventions. Today, almost no one advocates or uses " $\mathrm{j}$ " and I never saw it used as a variant in any elementary classroom.

Given all this, it is actually surprising that the " $\mathrm{j}$ " was not corrected by more students. In the town class, we find that 4 students retained the $" \mathrm{j} "$ and changed one or more

5 as well as following the third person singular of some irregular verbs ("to be" and "to have") and a limited number of other words like "chè," [that] "trè" [three] and perchè [because]. 
vowels in the word, and one student replaced the " $\mathrm{j}$ " with "g". There are several possible explanations for the students' failure to recognize normative orthographic practice at the same time as they manipulated the vowels. I find it plausible that they viewed the Corsican spelling system as more or less phonetic. In another questionnaire that I asked them to fill out about their experiences of French vs. Corsican literacy, most of the students in the town class wrote that Corsican was "easier" to spell than French. But French is probably the filter for their understandings of "easy" or direct sound-to-letter correspondences and thus the " $\mathrm{j}$ " may "look right" as the representation of the sound [dy].

The fact that the children changed the vowels in the word also demonstrates that they were using the Corsican spelling system as it was originally conceptualized: To represent regional variations in speech. All of the spellings they proposed reflect actual usage in and around the town where they live. In this respect, they exhibited a polynomic relationship to the spelling system. Given the way that I structured the exercise, we cannot tell if the children who wrote in these other variant pronunciations viewed their spelling as the single authoritative one, or if they were in effect identifying alternatives. But in either case, it is clear that they feel free to propose "phonetic" representations of their own pronunciations as a legitimate spelling, something they are by no means free to do in French.

\section{Table 4 French-Corsican contrast}

\begin{tabular}{|c|c|c|c|c|}
\hline $\begin{array}{l}\text { word circled, } \\
\text { followed by } \\
\text { alternative } \\
\text { proposed---> }\end{array}$ & $\begin{array}{l}\text { by town class } \\
(\mathrm{n}=10)\end{array}$ & $\begin{array}{l}\text { by village class } \\
(\mathrm{n}=11)\end{array}$ & by teachers $(n=11)$ & $\begin{array}{l}\text { total } \\
\text { times } \\
\text { word } \\
\text { circled } \\
\end{array}$ \\
\hline $\begin{array}{l}\text { bouttiglia } \\
\text { bottle }\end{array}$ & $\begin{array}{l}\text { no alt. (4) } \\
\text { buttiglia (2) } \\
\text { bouttilia (1) } \\
\text { boutiglia (1) } \\
\text { bouttigia (1) } \\
\end{array}$ & buttiglia (1) & $\begin{array}{l}\text { buttiglia (9) } \\
\text { no alt. (1) }\end{array}$ & 20 \\
\hline $\begin{array}{l}\text { Emu à } \\
\text { we will } \\
\text { (immediate future) } \\
\text { abbreviation of } \\
\text { 'avemu a' } \\
\end{array}$ & $\begin{array}{l}\text { no alt. (6) } \\
\text { Eiu (1) } \\
\text { Ému (1) } \\
\text { Ema (1) }\end{array}$ & emu dà (1) & $\begin{array}{l}\text { Emu da (5) } \\
\text { Avemu à (1) } \\
\text { Emu dà (1) } \\
\text { no alt. (1) }\end{array}$ & 19 \\
\hline $\begin{array}{l}\text { jente } \\
\text { people }\end{array}$ & $\begin{array}{l}\text { ghente (3) } \\
\text { jenti (2) } \\
\text { jinti (2) } \\
\text { gente (2) } \\
\text { no alt. (2) }\end{array}$ & ghjente (5) & $\begin{array}{l}\text { ghjente (7) } \\
\text { ? (1) } \\
\text { free variation (1) } \\
\text { no alt. (1) }\end{array}$ & 25 \\
\hline $\begin{array}{l}\text { avemu à } \\
\text { we will } \\
\text { (immediate future) }\end{array}$ & & & $\begin{array}{l}\text { avemu da (5) } \\
\text { no alt. (1) } \\
\text { avemu dà (1) }\end{array}$ & 7 \\
\hline
\end{tabular}

If we look at Table 5, however, we find that tolerance of pronunciation variants is not uniformly high or consistently reflected in the way all participants in the sample responded. 
So, we find that the word for Wednesday, spelled "Mercuri" and sometimes pronounced "Marcuri," attracted no attention from children and was identified as a free variant by less than half of the teachers. In the town class, the most probable explanation is that children had only ever seen the the word spelled as "Mercuri," since this reflects the dominant regional pronunciation. But in the village school, the teacher of the preschool through first grade class spelled this word "Marcuri" (which was the way she pronounced it) and the teacher of the second through fifth grade children spelled it "Mercuri." This exposure to spelling variation, therefore, did not "stick." This is, no doubt, partly because Corsican literacy is not taught explicitly until second grade, and I surveyed only the older children. This means that the spelling in the text I gave them reflected their current teacher's practice. However, it was also the case that the children wrote the day and date in Corsican in their notebooks every single day of the year starting in Kindergarten, which means that the respondents to the questionnaire had written "Wednesday" as "Marcuri" no less than 40 times. The same conditions hold for the word for "June". In the village school, the teacher of the smaller children's class said it and wrote it as "Ghjunghju" [dyundyu] and the teacher of the older children's class said it and wrote it as "Ghjungnu" [dyunyu]. In the exercise, 5 of the 11 children who were currently in the older class "corrected" the spelling that they had been exposed to in Kindergarten and first grade.

In the town class, 8 out of 10 children made the same correction, and the two other children in the class said that something was wrong with the spelling "ghjunghju". And, while three of the teachers acknowledged alternate pronunciations and spellings for this word, three of them also identified this spelling as an error, and an additional one started to circle it and then crossed out the circle and put an ambiguous mark on the page that looked like an underline. Further on in the text, the spelling of the word "June" as "ghjugnu," attracted almost no attention at all - in other words, it was taken as correct.

However, some spellings that reflected pronunciations that were less frequent for the region did not attract attention. For example, there is the word for "elephant," which I had used in the text as the name of a restaurant. Like the word for "June," this spelling reflected the way that the teacher of the preschool-first grade class said and wrote the word and contrasted with their current teacher's usage ("elifantu"), but in this case, none of the children in the village school "corrected" this spelling. There is some ambiguity surrounding this particular judgment related to the fact that the word was introduced as a restaurant name and thus may have been viewed as a proper noun that was not correctable. However, another spelling in the text that reflected a pronunciation that was non-normative for the region ("partimu") also attracted very little attention from students and teachers (only one of whom labeled it as a variant). Although a minority pronunciation for the region in general, "partimu" was used by many speakers from the town where the town school was located. Not only was this town only 11 kilometers from the village school but it was also home to several of the village school children. To summarize, then, it would seem that primary school children's consciousness of pronunciation variants was relatively limited geographically, and that most teachers were not making a deliberate effort to expose them to more geographically distant dialect features. Moreover, exposure to variation did not predict (either for the students or for the teachers) attitudes of acceptance. This was particularly striking with respect to the word for "June" among the children from the village class and, to a lesser extent, among the teachers (who "noticed" their own pronunciation "ghjugnu" less than the other form). The village children seemed to base their ideas of 
acceptability on the practice of their current teacher. This suggests the display of polynomy within the walls of their school (two teachers speaking and writing differently and accepting each other's varieties as valid) was not recognized by the children in the school.

Table 5: Pronunciation variants

\begin{tabular}{|c|c|c|c|c|}
\hline $\begin{array}{l}\text { word circled, } \\
\text { followed by } \\
\text { alternative } \\
\text { proposed---> }\end{array}$ & $\begin{array}{l}\text { by town class } \\
(\mathrm{n}=10)\end{array}$ & $\begin{array}{l}\text { by village class } \\
(\mathrm{n}=11)\end{array}$ & by teachers $(\mathrm{n}=11)$ & $\begin{array}{l}\text { total } \\
\text { times } \\
\text { word } \\
\text { circled }\end{array}$ \\
\hline $\begin{array}{l}\text { Mercuri } \\
\text { Wednesday }\end{array}$ & & & free variation (4) & 0 \\
\hline $\begin{array}{l}\text { i spesi } \\
\text { shopping }\end{array}$ & $\begin{array}{l}\text { no alt. (4) } \\
\text { e spese (2) } \\
\text { é spese (1) } \\
\text { pesi (1) }\end{array}$ & e spese (1) & $\begin{array}{l}\text { e spese (4) } \\
\text { circled and underlined (1) } \\
\text { "i" and "i" circled (1) }\end{array}$ & 15 \\
\hline $\begin{array}{l}\text { ghjunghju } \\
\text { June }\end{array}$ & $\begin{array}{l}\text { ghjungnu (8) } \\
\text { ghjunghjnu (1) } \\
\text { no alt. (1) }\end{array}$ & $\begin{array}{l}\text { ghjungnu (5) } \\
\text { ghjunghjnu (1) }\end{array}$ & $\begin{array}{l}\text { free variation (3) } \\
\text { one beginning of circle then } \\
\text { crossed out (?) } \\
\text { ghjungnu (2) } \\
\text { ghjughju (1) }\end{array}$ & 22 \\
\hline $\begin{array}{l}\text { partimu } \\
\text { we leavelare } \\
\text { leaving }\end{array}$ & & & free variation (1) & 0 \\
\hline $\begin{array}{l}\text { l'Alifante } \\
\text { The Elephant }\end{array}$ & & l'alifantu (1) & $\begin{array}{l}\text { free variation (2) } \\
\text { no alt. (1) }\end{array}$ & 4 \\
\hline $\begin{array}{l}\text { ghjugnu } \\
\text { June }\end{array}$ & & ghjungnu (1) & $\begin{array}{l}\text { free variation (1) } \\
\text { no alt. (1) }\end{array}$ & 2 \\
\hline
\end{tabular}

The final category of orthographic judgments I want to consider concerns spellings that are matters personal, esthetic preference. These are truly arbitrary spelling variants that have arisen through unregulated practice, and that have little connection with linguistic identity (either differentiation from French or Italian or association with a particular variety of Corsican). One kind of choice displayed in the text has to do with object pronouns following infinitives: The pronouns can either follow the verb as a separate word: "manghjà la" [to eat it] or be attached to the infinitive "accumpagnalla" [ to accompany it/her], in which case the infinitive loses its final accent and gains a double consonant ("1" in the previous case). Another similar esthetic choice concerns contracting or not contracting "it is" in writing: The full form is "ci hè" and the contracted form (which I used in the stimulus text) is "c'hè". I chose both these examples because they have been the recent objects of some fairly strong prescriptive positions in public discourse about orthography, and I have actually had my contracted use of "it is" corrected by Corsican University academics. These two deliberately planted examples were not, however, identified as errors by a significant number of respondents: Only two teachers expressed a preference for either one of the two infinitive+object choices and only one student identified the non-contracted "it is" as a more correct form than the contracted one. 
However, responses to the text revealed stronger attitudes about orthographic esthetics that I did not plant deliberately: "mo" for "my" and "be" for "for." Three children from the village class and one teacher circled "mo" and identified "mio" as the correct written form of "my." This is an interesting assertion of a literary register for Corsican, since the word for "my" is always pronounced "mo" in casual speech and "mio" is an Italian form that is only ever used in writing. This assertion is, in an indirect way, a challenge to the polynomic principle of the spelling system of Intricciate e Cambiarine, which has to do with the systematic graphic display of dialectal difference in spelling. Advocating the use of a superposed standard like "mio" foregrounds the issue of register (and the authority of written genres) at the expense of spoken difference (even though, in this case, there is only one pan-Corsican form). The other word I have included in Table 6 is "be" [for]. The two intended "errors" in this word were: 1 ) that the "b" was phonetic and not phonemic and "should" have been written as a "p" (which would be pronounced [b] in intervocalic contexts) and 2) that the ending was missing either an accent or an " $r$ ". Both the accented "-è" and the "-er" were used to signal the special status of this word with respect to the cambiarine: Even though the word "for" was pronounced $[\mathrm{p} \AA]$ or $[\mathrm{b} \AA]$ - thus ending with a vowel sound - consonants and consonant clusters that followed it were not "softened" or reduced. The results below suggest that most respondents had a personal preference for one or the other of these forms, possibly considering it "more correct." Of course, we have to keep in mind that the children were only asked to put "a" correct answer below anything they circled, so we have to be cautious in interpreting their results. However, it is striking that only 2 out of 10 teachers mentioned that there were two possible right answers.

Table 6: Orthographic Esthetics

\begin{tabular}{|c|c|c|c|c|}
\hline $\begin{array}{l}\text { word circled, } \\
\text { followed by } \\
\text { alternative } \\
\text { proposed---> }\end{array}$ & $\begin{array}{l}\text { by town class } \\
(\mathrm{n}=10)\end{array}$ & $\begin{array}{l}\text { by village class } \\
(\mathrm{n}=11)\end{array}$ & by teachers $(n=11)$ & \begin{tabular}{|l|} 
total \\
times \\
word \\
circled \\
\end{tabular} \\
\hline $\begin{array}{l}\text { mo } \\
\text { my (invariant) }\end{array}$ & & $\begin{array}{l}\text { mo (2) } \\
\text { miò (1) } \\
\text { mio (2) }\end{array}$ & $\begin{array}{l}\text { mio (1) } \\
\text { free variation (1) }\end{array}$ & 7 \\
\hline $\begin{array}{l}\text { c'era } \\
\text { it was (imperfect) }\end{array}$ & & ci era (1) & & 1 \\
\hline $\begin{array}{l}\text { accumpagnalla } \\
\text { accompany her/it }\end{array}$ & & & $\begin{array}{l}\text { free variation (1) } \\
\text { "la" circled (1) } \\
\text { accumpagna la (2) }\end{array}$ & 3 \\
\hline $\begin{array}{l}\text { mo } \\
\text { my (invariant) }\end{array}$ & & $\begin{array}{l}\text { mò (2) } \\
\text { mio (1) }\end{array}$ & $\begin{array}{l}\text { mio }(1) \\
\text { free variation (1) }\end{array}$ & 4 \\
\hline $\begin{array}{l}\text { be } \\
\text { to;for; in order to }\end{array}$ & $\begin{array}{l}\text { pè }(3) \\
\text { no alt. (3) } \\
\text { bè }(2) \\
\text { per }(1) \\
\text { bé }(1)\end{array}$ & pè (4) & $\begin{array}{l}\text { pè }(4) \\
\text { par }(1) \\
\text { pè or per }(2) \\
\text { per }(2) \\
\text { no alt }(1) \\
\end{array}$ & 24 \\
\hline $\begin{array}{l}\text { manghà la } \\
\text { to eat it }\end{array}$ & & & free variation $(2)$ & 0 \\
\hline
\end{tabular}




\section{Conclusions}

In contexts of language shift and revitalization, one form of resistance to dominant language ideologies is to propose new, plural models of linguistic identity and value. Polynomy is one such model. The data I have presented here suggest some of the difficulties of putting plural models such as this into practice, particularly in educational contexts. One set of difficulties is related to the fact that recognition of and resistance to hegemonic linguistic discourses is always situated in social practice, and thus within fields of power that are structured at a profound level by dominant language ideologies. With respect to language, we know that institutional practice in schools is overwhelmingly about identifying one correct way of speaking and writing; both teachers and students are accustomed to looking at language in this way. And, for at least half of the school week in bilingual schools (that is, when they were working in French) the teachers and students I studied were involved in a historically-embedded practice that took a single, authoritative norm absolutely for granted. This has several implications. First, work in French creates normative practice, including identifying one right answer.

Secondly, normative practice in French is an inevitable criterion of comparison between the two languages in Corsican bilingual schools, particularly with respect to their goal of sociolinguistic equity. In this framework, maintaining a polynomic perspective on standards in Corsican while enforcing a single French standard runs the risk of conveying the message that Corsican is less authoritative - less a legitimate linguistic system - than French. This is a message that most bilingual Corsican teachers would be loathe to send, since they view their schools as showcases for Corsican language status - as "anti-diglossia" propaganda.

In short, schools are political places, and the political playing fields in which minority language activists work, dominant language ideologies hold sway. So insisting on "mio" - or a literary register for Corsican - may have greater symbolic and political punch than making a claim for privileged pluralism. Put another way, all discourses about language are political, and most political discourses involve some form of "misrecognition." All in all, we see that incorporating a polynomic perspective into schools could involve a rather radical restructuring of school practice, for the general reasons I have outlined above and because of the specifics of the contemporary Corsican sociolinguistic situation. That is, teachers and students come to classrooms with limited linguistic/symbolic capital, and the ideal of polynomy requires an active interchange between equally powerful interlocutors. This is almost never the case in Corsican language education, whether targeted at children or adults. In this respect, it is fair to say that polynomy is itself a form of misrecognition, because it privileges a kind of linguistic equality in diversity that does not take account of the impact of language shift. Language shift has eroded both Corsican competence in general, and individual mastery of local varieties of Corsican. The new linguistic forms and identities produced by language shift do not revolve around Corsican dialectal diversity, but rather, around French-Corsican contact and dialect leveling and mixing brought on by academic teaching of the language. Polynomy does not embrace these kinds of linguistic variation.

Finally, it is clear that teaching plural ideologies of languages in school is fraught with difficulties. The results of the spelling evaluation exercise suggest that on Corsica, successfully teaching polynomy as an ideology of language identity would involve much 
more than just letting diversity in, because the overall framework of the school experience allows students to "misrecognize" polynomic practice. So in fact, teaching polynomy would require teachers to do more than display their individual rights to choose a speech or spelling variant that is different from another adult's. This is because the schooling experience does not tell students that they share all of their teachers' prerogatives, and teachers' polynomic practice can be interpreted by children as just another example of individual teacher's arbitrary imposition of their own standards within the classroom walls.

The demands of teaching polynomy are thus significantly different from the personal exercise of polynomy: They require teachers not just to use their own variety, but to actively perform and display diversity in speech and writing throughout the curriculum. As my discussion of the teacher training course shows, there are not many teachers who feel up to this task. Moreover, the active inclusion of diversity in the curriculum (including student assessments) conflicts with a view of authentic linguistic identity as local that underpins the polynomic program. The teacher who enacts multiple standards in the classroom undermines her status as a role model of authentic local speech and projects a model of active competence in other varieties that goes beyond the notion of "recognition" of unity in diversity on which polynomy is founded. Faced with children who do not speak any variety of Corsican, teachers and parents tend to advocate teaching that presents one coherent local variety (the precondition for participation in the polynomic universe as currently envisioned). Striving for this kind of competence in the school context shortcircuits the kind of inter-dialectal tolerance that is the philosophical basis of polynomy. In short, educational practice takes place within complex and overlapping fields of power, in which the boundaries of recognition and misrecognition are not always entirely clear.

\section{References}

Bourdieu, Pierre (1988) Homo Academicus. Trans. Peter Collier. Cambridge MA: Polity Press.

Fanon, Franz (1967) Black Skin, White Masks. New York: Grove Press.

Jaffe, Alexandra (1999) Ideologies in Action: Language Politics on Corsica. Berlin: Mouton de Gruyter.

Jaffe, Alexandra (1996) The Second Annual Corsican Spelling Contest: Orthography and ideology. American Ethnologist 23.4: 816-835.

Marcellesi, Jean-Baptiste (1989) Corse et théorie sociolinguistique: Reflets croisés. In Georges RavisGiordani (ed.), L'île miroir. Ajaccio: La Marge, pp. 165-174.

Memmi, Albert (1991) The Colonizer and the Colonized. New York: Beacon Press. 